\title{
Relationship between bodyweight and morphological traits in Sahelian goats of Nigeria using path analysis
}

\author{
Emmanuel Abayomi ROTIMI $\sim$ (D), Ojoh Michael MOMOH ${ }^{2}$ (D), Joseph Ochoche EGAHI ${ }^{2}$ (D) \\ ${ }^{1}$ Department of Animal Science, Federal University Dutsinma, Katsina State. Nigeria. \\ ${ }^{2}$ Department of Animal Breeding and Physiology, University of Agriculture Makurdi, Benue State. Nigeria.
}

\section{MAKALE BILGISI / ARTICLE INFO}

\section{Makale tarihçesi / Article history:}

DOI: $10.37908 /$ mkutbd.737231

Geliş tarihi /Received:14.05.2020

Kabul tarihi/Accepted:20.08.2020

\section{Keywords:}

Bodyweight, goats, morphological traits, path analysis sahel.

Corresponding author: Emmanuel Abayomi
ROTIMI
$\square$ : earotimi@gmail.com

\section{ÖZET / A B STR A C T}

\begin{abstract}
Aims: A total of 163 Sahelian goats of both sexes (64 males and 99 females) were randomly sampled and used in this study to assess the relationship between bodyweight and morphological traits using multivariate path analysis method.

Methods: Data were obtained on bodyweight (kg), height at withers (HW), body length (BL), paunch girth (PG) and heart girth (HG). Means $( \pm S D$ and $\mathrm{CV}$ ) and correlation coefficients between bodyweight and morphological parameters were also evaluated using the statistical procedures of SPSS 20.0 package.

Results: Higher significant $(\mathrm{P}<0.05)$ values were obtained for female goats in all the variables than males. The phenotypic correlation values between bodyweights and linear measurements were positive and highly significant $(r=0.707-0.803 ; P<0.01$ and $r=0.520-0.752 ; P<0.01)$ in male and female goats respectively. Results also revealed that the direct effect of paunch girth on bodyweight was strongest (path coefficient $=0.413$; $\mathrm{P}<0.05$ ) for males while body length was strongest (path coefficient = $0.373 ; \mathrm{P}<0.01$ ) for female goats.

Conclusions: The forecast indices recorded in this work could be employed to predict bodyweight in Sahelian goats with accuracy.

Significance and impact of study: The prediction model obtained in this study would be useful in weight estimation and in the process help in making management decision and breeding programs for genetic improvement in goats.
\end{abstract}

Atıf / Citation: Rotimi EA, Momoh OM, Egahi JO (2020) Relationship between bodyweight and morphological traits in Sahelian goats of Nigeria using path analysis. MKU. Tar. Bil. Derg. 25(3) : 455-460. DOI: 10.37908/mkutbd.737231

\section{INTRODUCTION}

Goats are the most numerous of all domesticated ruminants in Nigeria with an estimated population of 79.38 million, representing about $6.56 \%$ of the world's goat population (FAOSTAT. 2018). Goats play very important roles in the socio-cultural and socio-economic livelihoods of rural dwellers (Kosgey et al., 2008). Goats constitute an important source of livelihood and food security among the rural dwellers (Adebambo et al., 2011).

Bodyweight is crucial for proper management decisions and can be used to monitor and evaluate body development of farm animals (De Brito Ferreira et al., 2000). Bodyweight can be estimated using morphological traits (Yakubu, 2010a), simple phenotypic correlation relationships between bodyweight and morphological parameters (Gül et al., 2019; Kuzelove et al., 2011). These methods, however, are inadequate in explaining complex relationships between bodyweight and morphological traits due to the complex nature of bodyweight.

Correlations coefficients measure relationships between two variables whether influenced directly or indirectly. Path analysis is an alternative, which allows for the splitting of correlation coefficient into constituent parts 
called path coefficient (Marjanovic-Jeromela et al., 2007; Yakubu, 2011). It measures the direct and indirect effect of one variable on another and also partitions the correlation coefficients of the variables into components of direct and indirect effects (Akintunde, 2012; Yakubu and Mohammed, 2012). The path analysis model is a complementary methodology to regression analysis that permits the determination of independent variables that affects the dependent variable mostly (Jeonghoon, 2002; Keskin et al., 2005). Few authors have applied path analysis procedures to assess relationships between bodyweight and various body measurements in; West African Dwarf goats (Ogah et al., 2009), Red Sokoto goats (Yakubu and Mohammed, 2012), Yankasa lambs (Yakubu, 2010b), Bunaji cows (Yakubu, 2011), Awassi lamb (Gül et al., 2019), Turkey (Mendes et al., 2005). However, there was no such study in Sahelian goats in Nigeria.

This study used a path analysis approach to explore the relationships between bodyweight and linear body measurements of Sahelian goats in Nigeria and to determine the independent variables that largely affect bodyweight and have the potential to produce forecast indices at a higher degree of accuracy (Norris et al., 2015).

\section{MATERIALS and METHODS}

A total of 163 Sahelian goats of both sexes (64 males and 99 females) were randomly sampled and used in this study to assess the relationship between bodyweight and morphological traits using multivariate path analysis method. Goats were randomly sampled in villages located within Katsina state, Nigeria. Locations were purposively selected because of the preponderance of the targeted experimental animals. Katsina State lies between latitudes $12^{\circ} 59^{\prime} \mathrm{N}$ and longitudes $7^{\circ} 36^{\prime} \mathrm{E}$ with an elevation of about $519 \mathrm{~m}$ above the sea level (Anonymous, 2019).

Experimental animals were subjected to the traditional management grazing system which allowed them to graze freely during the day on natural pasture as available and returned to the homestead in the evening to owner care where they were provided with water and occasionally with kitchen wastes. The ages of the animals were estimated based on their dentition (FAO, 2012; Dereje et al., 2013).

Data were taken on live bodyweight $(\mathrm{kg})$ and four (4) morphological traits; height at withers (HW), body length (BL), paunch girth (PG) and heart girth (HG). Bodyweight $(\mathrm{kg})$ was taken using weighing scale, height at withers $(\mathrm{HW})$ was taken in centimeters $(\mathrm{cm})$ using meter ruler while body length (BL), paunch girth (PG) and heart girth $(\mathrm{HG})$ were taken in centimeters $(\mathrm{cm})$ using a simple Tailors' measuring tape.

Data collected were entered into Excel worksheet of Microsoft Excel 2016. Means, standard deviations (SD), and coefficients of variation (CV) for bodyweight (BWT), height at withers (HW), body length (BL), paunch girth (PG) and heart girth (HG) were obtained. Bivariate correlations among bodyweight and morphological traits were also obtained. The independent variables were screened to check the degree of multicollinearity by Variance Inflation Factors (VIF) and Tolerance (T) values, using SPSS (2011) statistical package. The initial values of the parameters measured were transformed to generate the standardized values from the unstandardized variables using Microsoft Excel 2016 procedures (Akintunde, 2012). The standardized data were then subjected to regression analysis using SPSS 20.0 statistical package. The path coefficient from an independent variable $(\mathrm{X})$ to a dependent variable $(\mathrm{Y})$ was estimated (Mendes et al., 2005).

$\mathrm{PY} . \mathrm{X}_{\mathrm{i}}=b i_{\mathrm{SY}}^{\mathrm{SXi}}$

Where;

$P Y . X_{i}=$ Path coefficient from $X_{i}$ to $Y(i=H W, B L, P G, H G)$

$b_{i}=$ Partial regression coefficient,

$S X_{i}=$ Standard deviation (SD) of $X_{i}$

$S Y=S t a n d a r d$ deviation (SD) of $Y$

The multiple linear regression model adopted is:

$Y=a+b_{1} X_{1}+b_{2} X_{2}+b_{3} X_{3}+b_{4} X_{4}+e$

where:

$\mathrm{Y}=$ Criterion variable (bodyweight; $\mathrm{BWT}$ ),

$\mathrm{a}=$ Intercept,

b1, b2, b3, b4 = Regression coefficients,

$\mathrm{X} 1, \mathrm{X} 2, \mathrm{X} 3, \mathrm{X} 4$ = Explanatory variables (HW, BL, PG, HG)

$\mathrm{e}=$ Residuals

In path analysis, it is assumed that residuals (error terms) are not correlated (Ulukan et al., 2003). The indirect effects (IE) of $X_{i}$ on $Y$ through $X_{j}$ was calculated as described by (Keskin et al., 2005; Norris et al., 2015).

$\mathrm{IE}\left(\mathrm{YX} \mathrm{X}_{\mathrm{i}}\right)=\left(\mathrm{r} \mathrm{X}_{\mathrm{i}} \mathrm{X}_{\mathrm{j}}\right) \cdot\left(\mathrm{PY} \cdot \mathrm{X}_{\mathrm{j}}\right)$

where:

$\mathrm{IE}\left(Y \mathrm{X}_{\mathrm{i}}\right)=$ Indirect effect of $\mathrm{X}_{\mathrm{i}}$ via $\mathrm{X}_{\mathrm{j}}$ on $\mathrm{Y}$, $r X_{i} X_{j}=$ Correlation coefficient $(r)$ between $i^{\text {th }}$ and $j^{\text {th }}$ independent variables,

PY. $X_{j}=$ Path coefficient indicating the direct effect of $j^{\text {th }}$ independent variable on the dependent variable.

\section{RESULTS and DISCUSSION}

The descriptive statistics of bodyweight and linear body measurements for male and female Sahelian goats are presented in Table 1. Sex had significant $(P<0.05)$ effects 
on BWT, HW, BL, PG, and HG where female goats had higher values than the male goats $(18.77 \mathrm{~kg}$ and 14.93 $\mathrm{kg}, 66.44 \mathrm{~cm}$ and $62.43 \mathrm{~cm}, 75.20 \mathrm{~cm}$ and $64.75 \mathrm{~cm}$, $73.27 \mathrm{~cm}$ and $66.02 \mathrm{~cm}, 59.54 \mathrm{~cm}$ and $54.34 \mathrm{~cm}$ respectively). The trend revealed the manifestation of sexual differentiations in the Sahelian goats. This is similar to the report of Ogah et al. (2009), who also observed that female West African Dwarf goats had higher values than their male counterparts except for rump height however, Okpeku et al. (2011) observed that males had higher mean values for all measured morphological measurements in indigenous goats in Southern Nigeria. Sebolai et al. (2012) reported significant differences in bodyweight between male and female for Tswana goats. Thiruvenkanden (2005) reported non-significant sex differences in bodyweight and body measurements of Kanni Adu goat kids of South India.

Table 1: Descriptive statistics for bodyweight $(\mathrm{kg})$ and body linear measurements $(\mathrm{cm})$ in male and female Sahelian goats

\begin{tabular}{llllll}
\hline Parameters & Sex & Mean & SE & SD & CV \\
\hline BWT $(\mathrm{kg})$ & $\mathrm{F}$ & $18.77^{\mathrm{a}}$ & 0.63 & 6.31 & 33.63 \\
& $\mathrm{M}$ & $14.93^{\mathrm{b}}$ & 0.75 & 5.96 & 39.93 \\
$\mathrm{HW}(\mathrm{cm})$ & $\mathrm{F}$ & $66.44^{\mathrm{a}}$ & 0.79 & 7.81 & 11.75 \\
& $\mathrm{M}$ & $62.43^{\mathrm{b}}$ & 1.03 & 8.23 & 13.18 \\
$\mathrm{BL}(\mathrm{cm})$ & $\mathrm{F}$ & $75.20^{\mathrm{a}}$ & 0.96 & 9.59 & 12.75 \\
& $\mathrm{M}$ & $64.75^{\mathrm{b}}$ & 1.13 & 8.10 & 13.90 \\
PG $(\mathrm{cm})$ & $\mathrm{F}$ & $73.27^{\mathrm{a}}$ & 0.93 & 9.27 & 12.65 \\
& $\mathrm{M}$ & $66.02^{\mathrm{b}}$ & 1.24 & 9.93 & 15.04 \\
$\mathrm{HG}(\mathrm{cm})$ & $\mathrm{F}$ & $59.54^{\mathrm{a}}$ & 0.91 & 9.09 & 15.26 \\
& $\mathrm{M}$ & $54.34^{\mathrm{b}}$ & 1.31 & 10.45 & 19.23 \\
\hline
\end{tabular}

BWT = bodyweight, $\mathrm{HW}=$ height at wither, $\mathrm{BL}$ = body length, $\mathrm{PG}=$ paunch girth, $\mathrm{HG}=$ heart girth, $\mathrm{F}=$ female, $\mathrm{M}=$ male, $\mathrm{SE}=$ standard error, $\mathrm{SD}=$ standard deviation, $\mathrm{CV}=$ coefficient of variation, ${ }^{\mathrm{a}, \mathrm{b}}$ Means having different superscripts between sex for same trait are significantly different $(P<0.05)$.

Table 2 presents the bivariate correlation coefficients displaying the relationship between bodyweight and all the linear body measurements of Sahelian goats. Correlations between bodyweight and the morphological traits were highly significant $(P<0.01)$ and positive. Highest correlations were observed between the bodyweight and PG in male and between body weight and height at withers in female goats $(r=0.803$ and 0.752 respectively).

Other linear body measurements were also highly significant $(P<0.01)$ and positively correlated. The implications of this highly significant $(P<0.01)$ positive correlations between bodyweight and morphological traits in the present study could be used to estimate live bodyweight from body measurements where weighing scales are not readily available or accessible. This association could also be useful in selection program for body weight improvement in goats.

High correlations between bodyweight and linear body measurements have been reported in; goat breeds (Ojedapo et al., 2007; Norris et al., 2015), Kanni Adu goat kids in South India (Thiruvenkanden, 2005), Yankassa lambs (Yakubu, 2010a), Nadji ram lambs (Aziz and Sharaby, 1993), Shami goats in Turkey (Gül et al., 2019) and sheep in South Africa (Kunene et al., 2009).

Table 2: Bivariate Pearson correlation coefficients among traits in Sahelian goats

\begin{tabular}{llllll}
\hline & BWT & HW & BL & PG & HG \\
\hline BWT & $\mathbf{1}$ & $0.784^{* *}$ & $0.707^{* *}$ & $0.803^{* *}$ & $0.750^{* *}$ \\
HW & $0.752^{* *}$ & 1 & $0.752^{* *}$ & $0.809^{* *}$ & $0.814^{* *}$ \\
BL & $0.732^{* *}$ & $0.606^{* *}$ & 1 & $0.855^{* *}$ & $0.638^{* *}$ \\
PG & $0.723^{* *}$ & $0.666^{* *}$ & $0.635^{* *}$ & 1 & $0.843^{* *}$ \\
HG & $0.520^{* *}$ & $0.610^{* *}$ & $0.297^{* *}$ & $0.603^{* *}$ & 1 \\
\hline
\end{tabular}

Male above diagonal and Female below diagonal, BWT = bodyweight, $\mathrm{HW}=$ height at wither, $\mathrm{BL}=$ body length, $\mathrm{PG}=$ paunch girth, $\mathrm{HG}=$ heart girth, ${ }^{* *}$. Correlation is significant $(\mathrm{P}<0.01)$. 
Tables 3 and 4 present the path coefficients of the explanatory variables of male and female Sahelian goats respectively. In male goats (Table 3 ), the highest direct positive contribution to bodyweight was made by the PG followed by HW $(0.413$ and 0.345 at $\mathrm{P}<0.05$ respectively). Highest correlation coefficient with body weight was recorded with PG $(r=0.803 ; P<0.01)$, its indirect effects (0.3899) was mostly realized via HW. The lowest direct effects (0.029) on body weight was recorded in $\mathrm{BL}$, its indirect effects (0.6776) was realized via PG. Most of the indirect contributions of the variables were realized via PG. It could be concluded that HW and PG are important for predicting bodyweight of male Sahelian goats with a high degree of accuracy.

Table 3: Direct and indirect effects of morphological traits on the bodyweight of male Sahelian goats

\begin{tabular}{llllllll}
\hline Trait & Correlation coefficient with BWT & Direct effects & \multicolumn{2}{c}{ Indirect effects } & \multicolumn{3}{c}{ Total } \\
& & & HW & BL & PG & HG & \\
\hline HW & $0.784^{* *}$ & $0.345^{*}$ & - & 0.0218 & 0.3345 & 0.0830 & 0.4393 \\
BL & $0.707^{* *}$ & $0.029 N S$ & 0.2594 & - & 0.3531 & 0.0651 & 0.6776 \\
PG & $0.803^{* *}$ & $0.413^{*}$ & 0.2791 & 0.0248 & - & 0.0860 & 0.3899 \\
HG & $0.750^{* *}$ & $0.102 N S$ & 0.2808 & 0.0185 & 0.3482 & - & 0.6475 \\
\hline
\end{tabular}

$\mathrm{BWT}=$ bodyweight, $\mathrm{HW}=$ height at wither, $\mathrm{BL}=$ body length, $\mathrm{PG}=$ paunch girth, $\mathrm{HG}=$ heart girth, ${ }^{* *}$ Significant at $\mathrm{P}<0.01$; *Significant at $\mathrm{P}<0.05, \mathrm{NS}$ : non-significant.

Table 4 presents the direct and indirect effects of morphological traits on bodyweight in female goats. The correlation coefficient between bodyweight and $\mathrm{HW}$ in this study was highest $(r=0.752 ; P<0.01)$, with direct effect on bodyweight (path coefficient $=0.329 ; \mathrm{P}<0.01$ ) and Its indirect effect $(0.4232$, realized mostly via body length. The highest direct effects were observed in $\mathrm{BL}$ (0.373) with high correlation with the body weight ( $r=$ $0.732 ; P<0.01)$, its indirect effects mainly realized via
HW. This indicates that bodyweight can be improved through direct selection for HW. This is followed by HW, having a significant direct effect $(0.329 ; \mathrm{P}<0.01)$, and its indirect effect on bodyweight was 0.4232 , realized mostly via BL. However, the direct effects of HW (0.093) were non-significant. Indirect effects obtained in this study were lower than the direct effects, except in BL, signifying that the variations observed were mainly due to the indirect effects.

Table 4: Direct and indirect effects of biometric traits on the bodyweight of female Sahelian goats

\begin{tabular}{llllllll} 
Trait & Correlation coefficient with BWT & Direct effects & \multicolumn{2}{c}{ Indirect effects } & \multicolumn{3}{c}{ Total } \\
& & & HW & BL & PG & HG & \\
\hline HW & $0.752^{* *}$ & $0.329^{* *}$ & - & 0.2260 & 0.1405 & 0.0567 & 0.4232 \\
BL & $0.732^{* *}$ & $0.373^{* *}$ & 0.1994 & - & 0.1340 & 0.0248 & 0.3582 \\
PG & $0.725^{* *}$ & $0.211^{*}$ & 0.2191 & 0.2369 & - & 0.0561 & 0.5121 \\
HG & $0.520^{* *}$ & $0.093 N S$ & 0.2007 & 0.0996 & 0.1272 & - & 0.4275 \\
\hline
\end{tabular}

$\mathrm{BWT}=$ bodyweight, $\mathrm{HW}=$ height at wither, $\mathrm{BL}=$ body length, $\mathrm{PG}=$ paunch girth, $\mathrm{HG}=$ heart girth, ${ }^{*}$ Significant at $\mathrm{P}<0.01$, *Significant at $\mathrm{P}<0.05$, NS $=$ non-significant

In this study, using path analysis procedures to show the relationship between body weight and morphological traits, the indirect effects of the independent variables on bodyweight were higher than the direct effects in both male and female goats. From this study, BL had the highest direct effects on body weight. Yakubu and Mohammed (2012) also used path analysis to show the relationship between bodyweight and morphological traits in Red Sokoto goats in Northern Nigeria, concluding that body length had the highest direct effect on bodyweight.

Tables 5 and 6 present the results of the regression analysis, in which standardized regression coefficients, t-statistical significance levels, and VIF values are given to explain the relationship between the other body measurements and bodyweight of male and female Sahelian goats. The results of the preliminary analysis in this study revealed that the VIF value for the independent variables were less than 10 in both cases while the tolerance $(T)$ was greater than 0.1 , in male and female goats, confirming that problem of Collinearity was not detected among the explanatory variables of the goats studied. 
Table 5: Results of regression preliminary analysis for male Sahelian goats

\begin{tabular}{lllll}
\hline Parameters & HW & BL & PG & HG \\
\hline Coefficient (b) & $0.345^{* *}$ & $0.029 \mathrm{NS}$ & $0.413^{*}$ & $0.102 \mathrm{NS}$ \\
VIF & 4.060 & 4.716 & 8.362 & 5.109 \\
Tolerance & 0.246 & 0.212 & 0.120 & 0.196 \\
R-squared & 0.699 & & & \\
\hline
\end{tabular}

$\mathrm{HW}=$ height at wither, $\mathrm{BL}=$ body length, $\mathrm{PG}=$ paunch girth, $\mathrm{HG}=$ heart girth, $\mathrm{SE}=$ standard error, $\mathrm{VIF}=$ Variance Inflation Factor, ${ }^{* *}$ Significant at $\mathrm{P}<0.01$; *Significant at $\mathrm{P}<0.05$, NS: non-significant.

Table 6: Results of regression preliminary analysis for female Sahelian goats

\begin{tabular}{lllll}
\hline Parameters & HW & BL & PG & HG \\
\hline Coefficient (b) & $0.329^{* *}$ & $0.373^{* *}$ & $0.211^{*}$ & $0.093 \mathrm{NS}$ \\
VIF & 2.477 & 2.105 & 2.621 & 2.022 \\
Tolerance (T) & 0.404 & 0.475 & 0.382 & 0.495 \\
R-squared & 0.722 & & & \\
\hline
\end{tabular}

$\mathrm{HW}=$ height at wither, $\mathrm{BL}=$ body length, $\mathrm{PG}=$ paunch girth, $\mathrm{HG}=$ heart girth, $\mathrm{SE}=$ standard error, $\mathrm{VIF}=$ Variance Inflation Factor, ${ }^{* *}$ Significant at $\mathrm{P}<0.01$; *Significant at $\mathrm{P}<0.05$, NS: non-significant.

From the regression analysis, regression model equations were derived for males and female goats. The derived regression model for male goats is:

$Y=-0.491+0.280 \mathrm{HW}+0.018 \mathrm{BL}+0.283 \mathrm{PG}+0.082 \mathrm{HG}$ While in female goats, the derived regression model equation is:

$\mathrm{Y}=-0.506+0.253 \mathrm{HW}+0.218 \mathrm{BL}+0.127 \mathrm{PG}+0.053 \mathrm{HG}$ The path coefficients of, $B L$ and $H G$ in male and $H G$ in female goats, were found statistically non-significant, and were expunged from the regression model. The simplified regression model was found to be:

For male goats; $Y=-0.504+0.315 \mathrm{HW}+0.335 \mathrm{PG}$ and the $R^{2}=0.697$ While in female goats, the derived regression model equation is:

For female goats; $Y=-0.514+0.288 \mathrm{HW}+0.200 \mathrm{BL}+$ $0.155 P G$ and the $R^{2}=0.717$

\section{CONCLUSIONS}

Correlation coefficients observed between BWT and morphological traits were positive and significant at $\mathrm{P}<0.01$, implying that the bodyweight of goats may be evaluated using morphological traits, particularly situations where scales are not readily available. The path analysis shows that PG and BL had the highest direct contributions to BWT in male and female goats respectively. The implication is that PG and $B L$ could be useful for selection and breeding programs in goat improvement for bodyweight.

\section{CONFLICT OF INTEREST}

The authors declare no conflict of interest for this study.

\section{AUTHOR'S CONTRIBUTIONS}

The contribution of the authors is equal.

\section{REFERENCES}

Adebambo AO, Adebambo O, Williams JL, Blott S, Urquart B (2011) Genetic distance between two popular Nigerian goat breeds used for milk production. Livestock Research for Rural Development 23 (26).

Akintunde RA (2012) Path analysis step by step using Excel. Journal of Technical Science and Technologies 1(1): 9-15.

Anonymous (2019) Distancesto.com. https://www.distancesto.com/coordinates/ng.

Aziz MA, Sharaby MA (1993) Collinearity as a problem in predicting body weight from body dimensions of Nadji sheep in Saudi Arabia. Small Ruminant Research 12: $117-124$.

De Brito Ferreira MP, Ramos De Carvalho FF, Nogueira Barros N, De Assis Mello A (2000) Relationship between body measurements and live weight in Saanen and Nubian goat breeds. Proceedings of the 7th International Conference on Goats, France, May 15-21.

Dereje T, Berhanu B, Aynalem H (2013) Morphological Characterization of Indigenous Hararghe Highland Goat Breed in their Native Environment, West Hararghe, Ethiopia. American-Eurasian Journal of Scientific Research 8 (2): 72-79.

FAO (2012) Phenotypic characterization of animal genetic resources. FAO Animal Production and Health Guidelines No.11. Rome, Italy. 
FAOSTAT

(2018)

https://

http://www.fao.org/faostat/en/\#data/QA.

Gül S, Keskin M, Güzey YZ, Behrem S, Gündüz Z (2019) Path analysis of the relationship between weaning weight and some morphological traits of Awassi lamb. KSU Tarım ve Doğa Derg. 22: 431-435.

Jeonghoon A (2002) Beyond single equation regression analysis: Path analysis and multi-stage regression analysis. American Journal of Pharmaceutical Education 66: 37-42.

Keskin A, Kor A, Karaca S, Mirtagioglu H (2005) A study of relationships between milk yield and some udder traits by using of path analysis in Akkeci goats. Journal of Animal and Veterinary Advances 4: 547-550.

Kosgey IS, Rowlands GJ, Van Arendonk JAM, Baker RL (2008) Small ruminant production in smallholder and pastoral/extensive farming systems in Kenya. Small Ruminant Research 77(1): 11-24.

Kunene NW, Nesamvuni AE, Nsahlai IV (2009) Determination of prediction equations for estimating body weight of Zulu (Nguni) sheep. Small Ruminant Research 84: 41-46.

Kuzelove A, Taskov N, Angelakova T, Atanasova E, Mladenov M (2011) Impact of live weight on the quality of pig halves and meat of the large white breed. Biotechnology in Animal Husbandry 27: 819824.

Marjanovic-Jeromela A, Marinkovic R, Mijic A, Zdunic Z, Ivanovska S, Jankulovska M (2007) Correlation and path analysis of quantitative traits in winter rapeseed (Brasssica napus L.). Agriculturae Conspectus Scientificus 73: 13-18.

Mendes M, Karabayir A, Pala A (2005) Path analysis of the relationship between various body measurements and live weight of American Bronze turkeys under three different lighting programs. Tarim Bilimleri Dergisi 11: 184-188.

Norris D, Brown D, Moela AK, Selolo TC, Mabelebele M, Ngambi JW, Tyasi TL (2015) Path coefficient and path analysis of body weight and biometric traits in indigenous goats. Indian Journal of Animal Research 49(5): 573-578.

Ogah MD, Hassan ID, Musa IS (2009) Path analysis of the relationship between various body measurements and live weight in immature West African Dwarf goats. Analele IBNA 25: 72-77.
Ojedapo LO, Adedeji TA, Olayeni TB, Adedeji OS, Abdullah AR, Ojebiyi OO (2007) Influence of age and sex on body weight and some body linear measurements of extensively reared WAD goats in derived savannah zone of Nigeria. Journal of Animal and Veterinary Advances 6: 114-117.

Okpeku M, Yakubu A, Peters SO, Ozoje MO, Ikeobi CON, Adebambo OA, Imumorin IG (2011) Application of multivariate principal component analysis to morphological characterization of indigenous goats in Southern Nigeria. Acta Agriculturae Slovenica 98 (2): 101-109.

Sebolai B, Nsoso SJ, Podisi B, Mokhutshwane BS (2012) The estimation of live weight based on linear traits in indigenous Tswana goats at various ages in Botswana. Tropical Animal Health and Production 44(4): 899-904.

SPSS (2011) Statistical Package for the Social Sciences. User's Guide: Statistics, Version 15.0. Institute, Inc., Cary, NC, USA.

Thiruvenkanden AK (2005) Determination of best fitted regression model for estimation of body weight in Kanni Adu kids under farmers' management systems. Livestock Research for Rural Development 17(7): 7687.

Ulukan H, Guler M, Keskin S (2003) A path coefficient analysis of some yield and yield components in Faba Bean (Vicia faba L.) genotypes. Pakistan Journal of Biological Sciences 6: 1951-1955.

Yakubu A (2010a) Path coefficient and path analysis of body weight and biometric traits in Yankasa lambs. Slovak Journal of Animal Science 43: 17-25.

Yakubu A (2010b) Fixing multicollinearity instability in the prediction of body weight from morphometric traits of White Fulani cows. Journal of Central European Agriculture 11: 487-492.

Yakubu A (2011) Path analysis of conformation traits and milk yield of Bunaji cows in smallholder herds in Nigeria. Agricultura Tropica et Subtropica 44 (3): 152157.

Yakubu A, Mohammed GL (2012) Application of path analysis methodology in assessing the relationship between body weight and biometric traits of Red Sokoto goats in Northern Nigeria. Biotechnology in Animal Husbandry 28 (1): 107-117. 